\title{
'DT-1', a Drought-tolerant Triploid Turf Bermudagrass
}

Brian M. Schwartz ${ }^{1}$, Wayne W. Hanna, and Lisa L. Baxter

Department of Crop and Soil Sciences, University of Georgia, Tifton Campus, 2360 Rainwater Road, Tifton, GA 31793

Paul L. Raymer and F. Clint Waltz

Department of Crop and Soil Sciences, University of Georgia, Griffin Campus, 1109 Experiment Street, Griffin, GA 30223

\author{
Alec R. Kowalewski \\ Department of Horticulture, Oregon State University, 2750 SW Campus Way, \\ Corvallis, OR 97331
}

Ambika Chandra and A. Dennis Genovesi

Department of Soil and Crop Sciences, Texas A\&M AgriLife ResearchDallas, 17360 Coit Road, Dallas, TX 75252

\section{Benjamin G. Wherley}

Department of Soil and Crop Sciences, Texas A\&M University, 370 Olsen Boulevard, College Station, Texas 77843

Grady L. Miller and Susana R. Milla-Lewis

Department of Crop and Soil Sciences, North Carolina State University, Campus Box 7620, Raleigh, NC 27695

William C. Reynolds

The Lawn Institute, Turfgrass Producers International, 444 E. Roosevelt Road, Suite 346, Lombard, IL 60148

\section{Yanqi Wu}

Department of Plant and Soil Sciences, Oklahoma State University, 223 Agricultural Hall, Stillwater, OK 74078

Dennis L. Martin and Justin Q. Moss

Department of Horticulture \& Landscape Architecture, Oklahoma State University, 358 Agricultural Hall, Stillwater, OK 74078

\section{Michael P. Kenna}

Green Section Research, United States Golf Association, 77 Liberty Corner Road, Liberty Corner, NJ 07938

\section{J. Bryan Unruh}

Agronomy Department, University of Florida, West Florida Research and Education Center, 4253 Experiment Road, Hwy 182, Jay, FL 32565

Kevin E. Kenworthy and Jing Zhang

Agronomy Department, University of Florida, P.O. Box 110965, Gainesville, FL 32611

\section{Patricio R. Munoz}

Horticultural Science Department, University of Florida, 2550 Hull Road, Gainesville, FL 32611

Additional index words. Cynodon dactylon, Cynodon transvaalensis, drought tolerance, Tifton, turfgrass quality

There are $\approx 20$ million hectares of turfgrass managed in the United States, constituting the $\$ 40$ billion turfgrass industry (National Turfgrass Federation, 2017). In most tropical and warm, temperate regions, bermudagrass (Cynodon spp.) is the foundation of the turfgrass industry (Taliaferro et al., 2004). Development of bermudagrass for turfgrass began in the early 1900 s. Much of this development has involved the hybridization of Cynodon dactylon (L.), a tetra- ploid recognized as an invasive weed species in many regions, and C. transvaalensis (Burt-Davy), a more erect-growing diploid (de Wet and Harlan, 1970; Harlan and de Wet, 1969). Early turfgrass-breeding programs have aimed to develop better bermudagrasses to replace sand putting greens or seeded varieties (i.e., Burton, 1991). Today, the goal of many breeding programs is to create cultivars that are adapted to a broader range of environments and have improved drought tolerance. The latter is particularly important, as irrigation restrictions during drought events are becoming more common. Improved drought tolerance allows turfgrass to maintain growth and metabolic activities under water deficits through physiological processes, including osmotic adjustment, maintenance of root viability, and membrane stability (Huang et al., 2014; Nilsen and Orcutt, 1996).

DT-1, an interspecific triploid $(2 n=3 x=$ 27) hybrid of $C$. transvaalensis and $C$. dactylon, was tested in 19 drought-stress trials in Georgia, Florida, North Carolina, Oklahoma, and Texas before it was co-released from the University of Georgia and the U.S. Department of Agriculture-Agricultural Research Service in 2014 and commercially named 'TifTuf' (Hanna and Schwartz, 2016). Potential uses of DT-1 include sports turfgrass, home lawns, and golf course roughs, fairways, and tee boxes. DT-1 better withstands drought and traffic than previous commercial releases. In addition, it is generally faster growing than other bermudagrass cultivars and maintains turfgrass cover and green color longer into the fall. The objective of this manuscript is to summarize the performance, quality, and drought tolerance research leading to the release of DT-1.

\section{Origin of DT-1}

In 1992, seven C. transvaalensis (T-572, T-573, T-573, T-574, T-575, T-576, and T577) parents were crossed with four $C$. dactylon (T-90, T-110, 'Quickstand', and 'VaMont') parents in Tifton, GA. Crosspollinations were made in the field by surrounding each $C$. transvaalensis parent with a $C$. dactylon parent in $1.9-\mathrm{m}^{2}$ plots. All crossing blocks were in close proximity of each other, so intercrossing between and among plots cannot be ruled out. On 7 May 1993 , more than 27,700 progeny from the cross combinations were planted on $46-\mathrm{cm}$ centers in the field. Once established, plots were mowed three times per week at $6.4 \mathrm{~mm}$. By the fall of 1994, 421 hybrids that maintained density under close mowing were selected, vegetatively propagated, and further evaluated in replicated tests until 1996. Ninety of these hybrids were selected based on turfgrass performance, vegetatively propagated, and planted on $30.5-\mathrm{cm}$ centers under a rainout shelter in 1999 and evaluated until 2001 under deficit irrigation. At the conclusion of this trial, one genotype was selected and named DT-1 because it maintained 
quality and green color longer than the others when under drought stress.

DT-1 was further tested in 19 droughtstress trials, two traffic-stress trials, and four irrigated, nonstress trials. These replicated field tests were carried out in Georgia, Florida, North Carolina, Oklahoma, and Texas. In addition, DT-1 was entered into the 2013 National Turfgrass Evaluation Program trials, where it was evaluated in 20 more locations across the United States.

\section{Description of Plant Material}

The morphology of DT-1 was compared with four bermudagrass cultivars in 2011 and 2012 in a replicated field trial in Tifton, GA (Table 1). DT-1 had a greater inflorescence density than 'TifSport' or 'Tifway', similar to 'Celebration', and less than 'TifGrand' (Table 1; Burton, 1966; Hanna et al., 1997, 2010). The inflorescence peduncle length (height) of DT-1 was taller than found in 'TifSport' or 'Tifway' and similar to 'Celebration' and 'TifGrand' (Table 1). DT-1 had a similar number of racemes per inflorescence as 'TifSport' and 'Tifway' but more than 'TifGrand' and less than observed in 'Celebration' (Table 1). DT-1's raceme length was similar to that of 'TifGrand' and less than found in 'Celebration', 'TifSport', and 'Tifway' (Table 1). DT-1 had fewer florets per raceme than 'Celebration', 'TifSport', or 'Tifway' but was similar to 'TifGrand' (Table 1). When left unmowed for more than 3 weeks, DT-1 had a higher canopy height than all other cultivars in this evaluation (Table 1). The leaf widths of DT-1, 'TifGrand', 'TifSport', and 'Tifway' were all similar, but DT-1's leaves were narrower than those of 'Celebration' (Table 1). DT-1's terminal stolon internode lengths were similar to those of 'TifGrand' and 'Tifway' but less than found on 'Celebration' and 'TifSport' (Table 1).

The genetic turfgrass color of DT-1 rated lower than observed in all other tested cultivars based on visual ratings in an irrigated field trial in Tifton, GA, during 2011 and

Received for publication 20 Mar. 2018. Accepted for publication 16 Sept. 2018.

This research was funded in part by the University of Georgia College of Agriculture \& Environmental Sciences, the United States Department of AgricultureAgricultural Research Service (USDA-ARS), the University of Georgia Research Foundation, Georgia Seed Development, the United States Golf Association, and by the National Institute of Food and Agriculture, U.S. Department of Agriculture, under award number 2010-51181-21064. We express appreciation for the technical expertise of Larry Baldree, Amanda Webb, John Schaffner, and Lewayne White. Any opinions, findings, conclusions, or recommendations expressed in this publication are those of the author(s) and do not necessarily reflect the view of the U.S. Department of Agriculture.

${ }^{1}$ Corresponding author. E-mail: tifturf@uga.edu. This is an open access article distributed under the CC BY-NC-ND license (http://creativecommons. org/licenses/by-nc-nd/4.0/).

Table 1. Inflorescence and vegetative plant morphology of five bermudagrass genotypes measured during 2011 and 2012 in Tifton, GA. ${ }^{z}$

\begin{tabular}{|c|c|c|c|c|c|c|c|c|}
\hline Genotype & $\begin{array}{c}\text { Inflorescences } \\
\text { per } \mathrm{m}^{2} \text { (no.) }\end{array}$ & $\begin{array}{c}\text { Inflorescence } \\
\text { peduncle } \\
\text { length }(\mathrm{mm})\end{array}$ & $\begin{array}{c}\text { Racemes per } \\
\text { inflorescence } \\
\text { (no.) }\end{array}$ & $\begin{array}{l}\text { Raceme } \\
\text { length } \\
(\mathrm{mm})\end{array}$ & $\begin{array}{c}\text { Florets } \\
\text { per } \\
\text { raceme } \\
\text { (no.) }\end{array}$ & $\begin{array}{c}\text { Turfgrass } \\
\text { canopy } \\
\mathrm{ht}^{\mathrm{y}}(\mathrm{cm})\end{array}$ & $\begin{array}{c}\text { Leaf } \\
\text { width }^{\mathrm{x}} \\
(\mathrm{mm})\end{array}$ & $\begin{array}{l}\text { Stolon } \\
\text { internode } \\
\text { length }^{\mathrm{w}} \\
(\mathrm{mm})\end{array}$ \\
\hline Celebration & $3,679 \mathrm{ab}^{\mathrm{v}}$ & $66 \mathrm{a}$ & $3.6 \mathrm{a}$ & $36 \mathrm{a}$ & $38.3 \mathrm{a}$ & $9 \mathrm{~b}$ & $2.2 \mathrm{a}$ & $25 \mathrm{ab}$ \\
\hline DT-1 & $2,940 \mathrm{~b}$ & $67 \mathrm{a}$ & $2.9 \mathrm{~b}$ & $22 \mathrm{c}$ & $13.2 \mathrm{c}$ & $17 \mathrm{a}$ & $1.8 \mathrm{~b}$ & $17 \mathrm{c}$ \\
\hline TifGrand & $4,232 \mathrm{a}$ & $62 \mathrm{a}$ & $2.3 \mathrm{c}$ & $22 \mathrm{c}$ & $15.6 \mathrm{bc}$ & $9 \mathrm{~b}$ & $2.0 \mathrm{ab}$ & $18 \mathrm{c}$ \\
\hline TifSport & $535 \mathrm{c}$ & $53 \mathrm{~b}$ & $2.8 \mathrm{~b}$ & $25 \mathrm{~b}$ & $16.3 \mathrm{~b}$ & $10 \mathrm{~b}$ & $1.8 \mathrm{~b}$ & $25 \mathrm{ab}$ \\
\hline Tifway & $407 \mathrm{c}$ & $48 \mathrm{~b}$ & $2.8 \mathrm{~b}$ & $25 \mathrm{~b}$ & $16.8 \mathrm{~b}$ & $9 \mathrm{~b}$ & $1.9 \mathrm{~b}$ & $21 \mathrm{bc}$ \\
\hline
\end{tabular}

${ }^{\mathrm{z}}$ Field trial planted during 2010.

${ }^{\mathrm{y}}$ Turfgrass canopy heights were measured from the ground to the top of the leaves.

${ }^{\mathrm{x}}$ Leaf widths were measured on the first fully expanded leaf of a mature phytomer in the turfgrass canopy. ${ }^{\text {w }}$ Stolon internode lengths were measured between the third and fourth node of the apical meristem.

${ }^{v}$ Means within columns followed by the same letter are not significantly different at alpha $=0.05$. Data were analyzed with PROC GLM in SAS 9.4 (SAS Inc., Cary, NC).

2012 (Table 2). Digital image analysis (Karcher and Richardson, 2003; Richardson et al., 2001) performed on an irrigated, nonstressed field trial in Tifton, GA, during 2012 and 2013 revealed that DT-1 generally had a lower dark green color index value than other cultivars under evaluation throughout the growing season (Table 3). DT-1 was similar in color to 'TifSport' at establishment but lighter green than 'Celebration' or 'TifGrand' (Table 3). Although DT-1 was the lightest green cultivar at spring green-up, it was similar to 'TifSport' during the summer period (Table 3). When color was measured during fall dormancy, the color measured in DT-1 was less than 'Celebration' but similar to 'TifGrand' and 'TifSport' (Table 3).

DT-1 had a faster growth rate during establishment than 'TifGrand' or 'TifSport', but it covered more slowly than 'Celebration' in a regularly irrigated, nonstressed trial conducted in Tifton, GA, in 2012 and 2013 (Table 3). When moisture was not limiting, the spring green-up of DT-1 was faster than observed in 'Celebration' and 'TifGrand' but equal to that of 'TifSport' (Table 3). No difference was seen in turfgrass cover among the cultivars during the summer (Table 3 ). Green cover during fall dormancy was greater in DT-1 than 'Celebration', 'TifGrand', or 'TifSport' (Table 3).

In nonirrigated stress trials conducted in Tifton, GA, from 2009 to 2011, DT-1 generally maintained greater turfgrass quality and green cover than 'TifSport' and 'Tifway' from spring green-up to fall dormancy (Table 4). The one exception was during periods of summer with sufficient rainfall to mitigate the stressed environment; here, 'TifSport' maintained similar coverage to the otherwise-superior DT-1. Percent green cover and cumulative water use were evaluated under drought conditions in a field trial conducted in Griffin, GA, in 2011 (Fig. 1; PR2 Profile Probe, Delta-T Devices Ltd., Cambridge, United Kingdom). A significant difference in turfgrass cover was observed between 'Tifway' and DT-1 after just $3 \mathrm{~d}$ of drought conditions (Fig. 1A; $P>0.05)$. Soil moisture was greater in DT-1 plots once the drought exceeded $7 \mathrm{~d}$ (Fig. 1B; $P>0.10$ ). The mechanism of DT-1's drought tolerance appears to be
Table 2. Mean genetic turfgrass color of six bermudagrasses averaged over control and trinexapac-ethyl $(\mathrm{TE})^{\mathrm{z}}$ treatments mowed at $2.54 \mathrm{~cm}$ in an irrigated field trial during 2011 and 2012 in Tifton, GA. ${ }^{y}$

\begin{tabular}{lll}
\hline & \multicolumn{2}{c}{ Turfgrass color $^{\mathrm{x}}$} \\
\cline { 2 - 3 } Genotype & \multicolumn{1}{c}{2011} & 2012 \\
\hline Celebration & $7.1 \mathrm{bc}^{\mathrm{w}}$ & $7.1 \mathrm{~cd}$ \\
Discovery & $8.0 \mathrm{a}$ & $8.9 \mathrm{a}$ \\
DT-1 & $6.1 \mathrm{~d}$ & $6.0 \mathrm{e}$ \\
Patriot & $7.4 \mathrm{~b}$ & $6.9 \mathrm{~d}$ \\
TifGrand & $7.3 \mathrm{bc}$ & $7.8 \mathrm{bc}$ \\
Tifway & $6.9 \mathrm{c}$ & $8.3 \mathrm{ab}$ \\
\hline
\end{tabular}

${ }^{\mathrm{z}} \mathrm{TE}$ applications were made the first week of the month in June, July, Aug., and Sept. 2011 and 2012 at a rate of $0.15 \mathrm{~kg} \cdot \mathrm{ha}^{-1}$.

${ }^{\mathrm{y}}$ Field trial planted during 2011.

${ }^{\mathrm{x}}$ Genetic turfgrass color visually assessed on a 1 to 9 scale with $1=$ yellow, $6=$ acceptable, and $9=$ dark green $20 \mathrm{~d}$ after the August TE application.

${ }^{\mathrm{w}}$ Means within columns followed by the same letter are not significantly different at alpha = 0.05 . Data were analyzed with PROC GLM in SAS 9.4 (SAS Inc., Cary, NC).

reduced water use. These data suggest that under prolonged drought events (those exceeding 7 d), DT-1 can maintain greater green cover with less irrigation.

The visual quality of DT-1 compared with three other bermudagrass varieties was evaluated in 2013 and 2014 in five locations throughout the southern and transition zones of the United States (College Station, TX; Dallas, TX; Gainesville, FL; Raleigh, NC; Stillwater, OK; Table 5). There were no significant interactions among locations or years in nonstressed environments $(P>0.15)$, so data were further combined across locations for this particular analysis. DT-1 had greater quality in nonstressed environments than 'Latitude 36' and 'Celebration' and was similar to 'Tifway' (Table 5; $P<0.01$ ).

There were significant genotype $\times$ year and genotype $\times$ location interactions when turfgrass quality was measured during drought events $(P<0.01)$. When the data were reanalyzed by location, the genotype $x$ year interactions at each location were either not significant or significant differences were caused by a magnitude of response rather than a direction of response. Therefore, data were averaged over years. DT-1 turfgrass quality was numerically greater than the 
Table 3. Mean turfgrass cover and color of five bermudagrasses mowed at $3.8 \mathrm{~cm}$ in an irrigated, nonstressed field trial during 2012 and 2013 in Tifton, GA. ${ }^{2}$

\begin{tabular}{|c|c|c|c|c|c|c|c|c|}
\hline \multirow[b]{3}{*}{ Genotype } & \multicolumn{4}{|c|}{ Turfgrass color } & \multicolumn{4}{|c|}{ Turfgrass cover ${ }^{x}$} \\
\hline & Establishment & $\begin{array}{c}\text { Spring } \\
\text { green-up }\end{array}$ & Summer & $\begin{array}{c}\text { Fall } \\
\text { dormancy }\end{array}$ & Establishment & Spring green-up & Summer & Fall dormancy \\
\hline & \multicolumn{4}{|c|}{-----------------------------------DGCI -------------------------------- } & \multicolumn{4}{|c|}{ 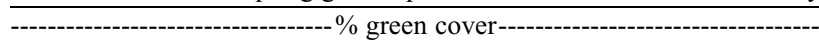 } \\
\hline TifGrand & $0.85 \mathrm{a}$ & $0.63 \mathrm{~b}$ & $0.72 \mathrm{a}$ & $0.70 \mathrm{~b}$ & $26 \mathrm{c}$ & $46 \mathrm{~d}$ & $85 \mathrm{a}$ & $47 \mathrm{~b}$ \\
\hline TifSport & $0.82 \mathrm{~b}$ & $0.65 \mathrm{a}$ & $0.70 \mathrm{~b}$ & $0.68 \mathrm{~cd}$ & $32 \mathrm{c}$ & $75 \mathrm{a}$ & $86 \mathrm{a}$ & $33 \mathrm{c}$ \\
\hline DT-1 & $0.81 \mathrm{~b}$ & $0.60 \mathrm{c}$ & $0.69 \mathrm{~b}$ & $0.68 \mathrm{bc}$ & $44 \mathrm{~b}$ & $75 \mathrm{a}$ & $91 \mathrm{a}$ & $65 \mathrm{a}$ \\
\hline $\mathrm{T}-11^{\mathrm{v}}$ & $0.85 \mathrm{a}$ & $0.63 \mathrm{~b}$ & $0.71 \mathrm{ab}$ & $0.66 \mathrm{~d}$ & $48 \mathrm{ab}$ & $54 \mathrm{c}$ & $91 \mathrm{a}$ & $26 \mathrm{c}$ \\
\hline
\end{tabular}

${ }^{\mathrm{z}}$ Field trial planted during 2009.

${ }^{\mathrm{y}}$ Turfgrass color was determined by analyzing digital images taken in an enclosed photo box with a constant light source using SigmaScan Pro (Systat Software Inc., San Jose, CA) to measure the hue, saturation, and brightness and then calculate the DGCI.

${ }^{\mathrm{x}}$ Turfgrass cover was determined by analyzing digital images taken in an enclosed photo box with a constant light source using SigmaScan Pro to measure the percentage of green pixels $(0 \%$ to $100 \%)$.

${ }^{\mathrm{w}}$ Means within columns followed by the same letter are not significantly different at alpha $=0.05$. Data were analyzed with PROC GLM in SAS 9.4 (SAS Inc., Cary, NC).

${ }^{\mathrm{v}} \mathrm{T}-11$ is an experimental line in Tifton, GA, but has not been discussed in this manuscript.

$\mathrm{DGCI}=$ dark green color index.

Table 4. Mean turfgrass quality and cover of three bermudagrasses mowed at $3.8 \mathrm{~cm}$ in a nonirrigated field trial during 2009, 2010, and 2011 in Tifton, GA. ${ }^{2}$

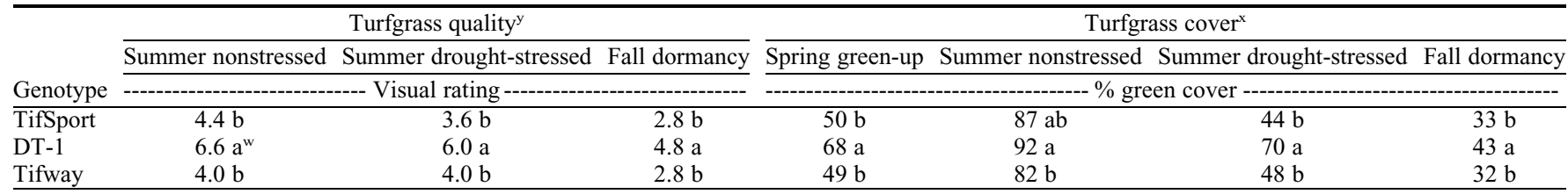

${ }^{\mathrm{z}}$ Field trial planted during 2006 .

${ }^{\mathrm{y}}$ Turfgrass quality was rated on a 1 to 9 scale with $1=$ dead, $5=$ acceptable, and $9=$ excellent.

${ }^{\mathrm{x}}$ Turfgrass cover was determined by analyzing digital images taken in an enclosed photo box with a constant light source using SigmaScan Pro (Systat Software Inc., San Jose, CA) to measure the percentage of green pixels ( $0 \%$ to $100 \%)$.

${ }^{\mathrm{w}}$ Means within columns followed by the same letter are not significantly different at alpha $=0.05$. Data were analyzed with PROC GLM in SAS 9.4 (SAS Inc., Cary, NC).

other three cultivars in all five locations, but there were no differences among cultivars in College Station, TX (Table 5; $P=0.18$ ). DT1 turfgrass quality was similar to 'Celebration' and greater than 'Latitude 36' and 'Tifway' in Dallas, TX (Table 5; $P<0.01$ ). DT-1 was similar to 'Tifway' but greater than the other two cultivars in Gainesville, FL (Table 5; $P<0.01$ ). In Raleigh, NC, DT-1 had similar quality to 'Latitude 36 '; both were greater than 'Celebration' and 'Tifway' at this location (Table 5; $P<0.01$ ). DT-1 produced greater quality than all other cultivars in Stillwater, OK (Table 5; $P<0.01$ ).

DT-1 had superior traffic tolerance to 'Celebration', 'TifGrand', and 'Tifway' when subjected to more than 6 weeks of traffic in Tifton, GA during 2012 and 2013 (weeks indicated by stars in Fig. 2; $P<0.05$; Kowalewski et al., 2013). The mechanism of DT-1's wear traffic tolerance may be its increased canopy density, particularly in the fall months, as illustrated by the percent green plot coverages that were estimated by digital image analysis in the untrafficked treatment of Fig. $2(P<$ 0.05; also Table 4). The faster growth rate described in Tables 3 and 4 likely contributed to the resilience of DT-1 as well.

\section{Culture}

DT-1 does not produce seed or pollen, so it must be vegetatively propagated by sprigs, plugs, or sod. A potential limitation of DT-1 is that it can scalp when mowing frequency is not regular in environments in which soil water and nutrient availability
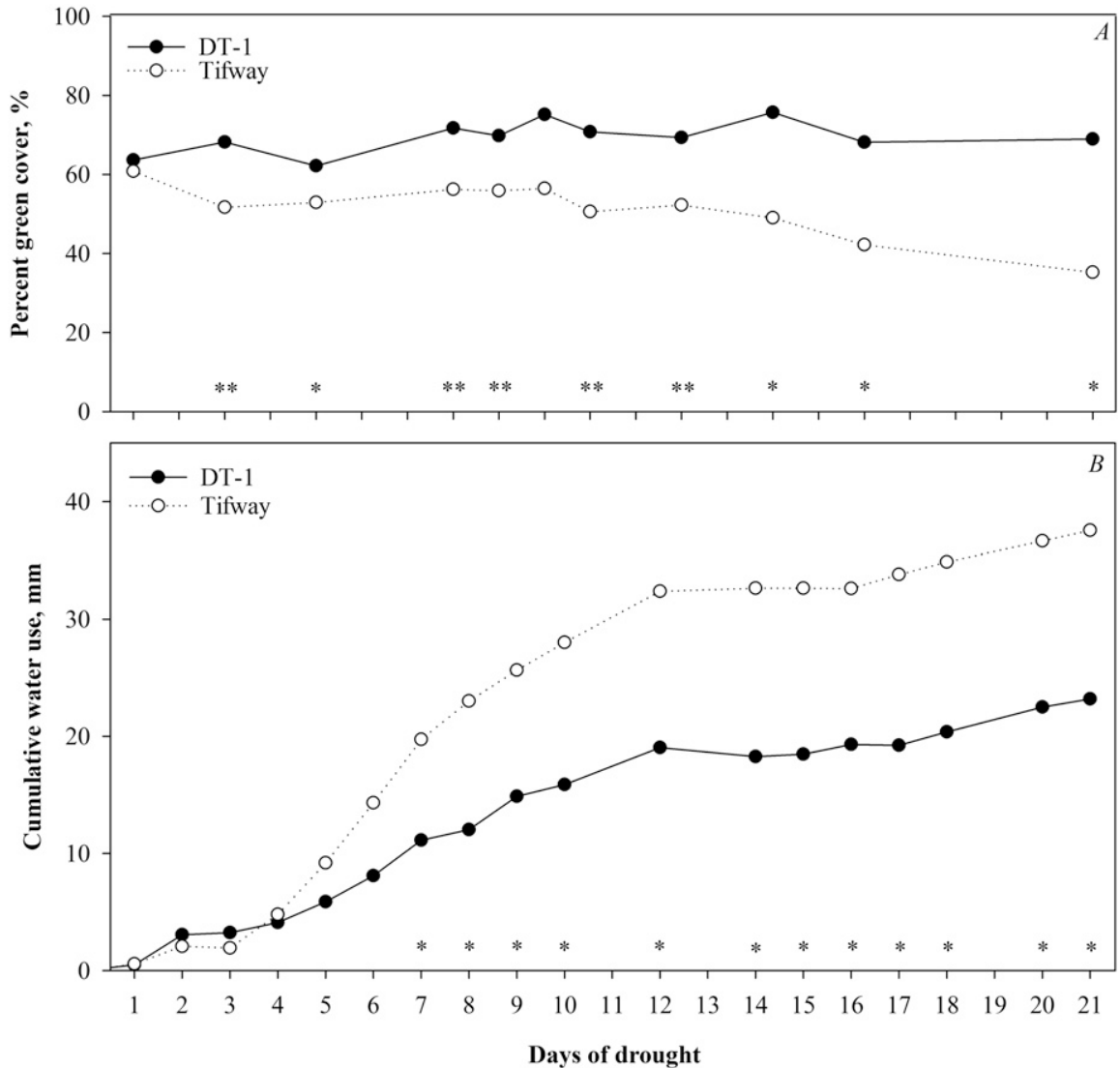

Fig. 1. Mean percent green cover determined by digital image analysis $(\mathbf{A})$ and cumulative water use using $40-\mathrm{cm}$ soil moisture profile probes $(\mathbf{B})$ of two bermudagrasses mowed at $5.1 \mathrm{~cm}$ over $21 \mathrm{~d}$ without irrigation in a 2011 field trial in Griffin, GA. Mean turfgrass cover is significantly different where asterisks are present along the $\mathrm{x}$-axes $[* * P$ value $<0.05 ; * P$ value $<0.10$; data were analyzed with PROC GLM in SAS 9.4 (SAS Inc., Cary, NC)]. Field trial was planted in 2010. 
Table 5. Mean turfgrass quality ${ }^{\mathrm{z}}$ of four bermudagrasses mowed at 2.4 to $3.8 \mathrm{~cm}$ in nonirrigated field trials during 2013 and 2014 in five locations. ${ }^{\mathrm{y}}$ Data were collected during periods of sufficient rainfall and drought stress. Nonstressed data are averaged overall five locations and both years. Drought-stressed data are averaged over both years within each location.

\begin{tabular}{|c|c|c|c|c|c|c|}
\hline \multirow[b]{2}{*}{ Genotype } & \multirow{2}{*}{$\frac{\text { Nonstressed }}{\text { All locations }}$} & \multicolumn{5}{|c|}{ Drought-stressed } \\
\hline & & College Station, TX & Dallas, TX & Gainesville, FL & Raleigh, NC & Stillwater, OK \\
\hline & \multicolumn{6}{|c|}{ Visual rating } \\
\hline DT-1 & $6.3 \mathrm{a}^{\mathrm{x}}$ & $5.9^{\mathrm{w}}$ & $7.2 \mathrm{a}$ & $7.1 \mathrm{a}$ & $6.1 \mathrm{a}$ & $5.4 \mathrm{a}$ \\
\hline Tifway & $5.9 \mathrm{ab}$ & 5.6 & $5.9 \mathrm{~b}$ & $6.6 \mathrm{a}$ & $5.3 \mathrm{~b}$ & $4.4 \mathrm{~b}$ \\
\hline Latitude 36 & $5.6 \mathrm{bc}$ & 5.4 & $4.2 \mathrm{c}$ & $4.3 \mathrm{~b}$ & $5.3 \mathrm{ab}$ & $4.3 \mathrm{~b}$ \\
\hline Celebration & $5.2 \mathrm{c}$ & 5.2 & $6.1 \mathrm{ab}$ & $5.3 \mathrm{~b}$ & $4.2 \mathrm{c}$ & $4.4 \mathrm{~b}$ \\
\hline
\end{tabular}

${ }^{\mathrm{z}}$ Turfgrass quality was rated on a 1 to 9 scale with $1=$ dead, $5=$ acceptable, and $9=$ excellent.

${ }^{\mathrm{y}}$ Field trials planted during 2012.

${ }^{\mathrm{x}}$ Means within columns followed by the same letter are not significantly different at alpha $=0.05$. Data were analyzed with PROC MIXED in SAS 9.4 (SAS Inc., Cary, NC).

${ }^{\mathrm{w}}$ No significant differences were found in the trial at College Station, TX.
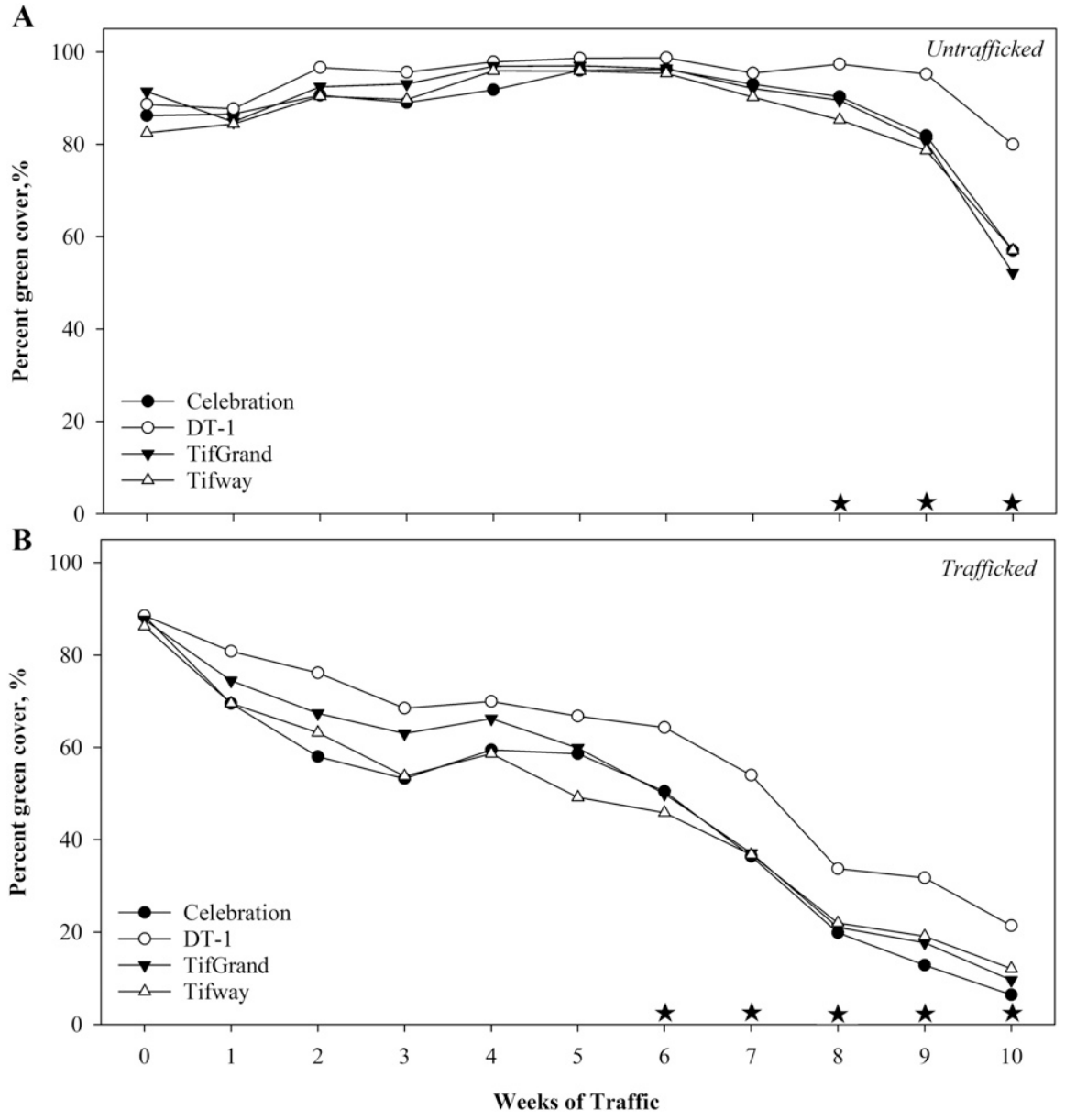

Fig. 2. Mean percent green cover determined by digital image analysis of four bermudagrasses mowed at $2.54 \mathrm{~cm}$ over 10 weeks with and without simulated traffic in an irrigated field trial during Fall 2012 and 2013 in Tifton, GA. Significant differences among varieties were observed in weeks 3, 4, 8, 9, and 10 for the untrafficked control (A); and weeks 1, 2, 3, 4, 6, 7, 8, 9, and 10 under the traffic treatment (B) $[$ alpha $=0.05$; data were analyzed with PROC GLM in SAS 9.4 (SAS Inc., Cary, NC) ]. Stars indicate that mean percent green cover of DT-1 is significantly greater than all other tested cultivars within respective traffic treatments. Field trial planted during 2011.

are not limiting (Table 1). The potential of DT-1 to scalp has not been an issue in stress environments. Potential users of DT-1 bermudagrass would be the sod industry, sports turfgrass managers, landscape professionals, homeowners, and golf course superintendents maintaining turf at or above $1.27 \mathrm{~cm}$ (e.g., roughs, fairways, and tee boxes but not putting greens). DT-1 was thoroughly tested in the
DT-1 is protected by U.S. Patent No. PP27,392 and has been submitted to the USDA-ARS Plant Genetic Resources Conservation Unit in Griffin, GA, where it is cataloged as PI 677384. DT-1 breeder planting
United States and should be widely adapted between the latitudes of $36 \mathrm{~N}$ and $36 \mathrm{~S}$.

\section{Availability}

material is maintained in the breeder nursery at the University of Georgia Tifton Campus. Because DT-1 is a patented cultivar, it may only be produced by licensed growers under guidelines established by the University of Georgia Research Foundation in conjunction with Georgia Seed Development. Contact Georgia Seed Development (http://www. gsdc.com) for information on availability.

\section{Literature Cited}

Burton, G.W. 1966. Tifway (Tifton 419) bermudagrass. Crop Sci. 6:93-94.

Burton, G.W. 1991. A history of turf research at Tifton. USGA Green Sect. Rec. 29:12-14.

de Wet, J.M.J. and J.R. Harlan. 1970. Biosystematics of Cynodon L. C. Rich. (Gramineae). Taxon 19:565-569.

Hanna, W.W. and B.M. Schwartz. 2016. Bermudagrass named 'DT-1'. US Plant Patent 27,392 P2. Date issued: 15 Nov.

Hanna, W.W., R.N. Carrow, and A.J. Powell. 1997. Registration of 'Tift 94' bermudagrass. Crop Sci. 37:1012.

Hanna, W.W., S.K. Braman, and B.M. Schwartz. 2010. 'ST-5', a shade-tolerant turf bermudagrass. HortScience 45:132-134.

Harlan, J.R. and J.M.J. de Wet. 1969. Sources of variation in Cynodon dactylon (L.). Pers. Crop Sci. 9:774-777.

Huang, B., M. DaCosta, and Y. Jiang. 2014. Research advances in mechanisms of turfgrass tolerance to abiotic stresses: From physiology to molecular biology. Crit. Rev. Plant Sci. 33:141-189.

Karcher, D.E. and M.D. Richardson. 2003. Quantifying turfgrass color using digital image analysis. Crop Sci. 43:943-951.

Kowalewski, A.R., B.M. Schwartz, A.L. Grimshaw, D.G. Sullivan, J.B. Peake, T.O. Green, J.N Rogers, III, L.J. Kaiser, and H.M. Clayton. 2013. Biophysical effects and ground force of the Baldree Traffic Simulator. Crop Sci. 53: 2239-2244.

National Turfgrass Federation. 2017. The turfgrass industry-present and future. $25 \mathrm{Jan}$. 2018. <http://www.turfresearch.org/pdf/ Industry\%20Turf\%20Initiative.pdf $>$.

Nilsen, E.T. and D.M. Orcutt. 1996. The physiology of plants under stress. Wiley, New York.

Richardson, M.D., D.E. Karcher, and L.C. Purcell 2001. Quantifying turfgrass cover using digital image analysis. Crop Sci. 41:1884-1888.

Taliaferro, C.M., F.M. Rouquette, and P. Mislevy. 2004. Bermudagrass and stargrass, p. 417-475. In: L.E. Moser, B.L. Burson, and L.E. Sollenberger (eds.). Warm-season (C4) grasses, Agronomy Monograph No. 45. American Society of Agronomy, Madison.

HortScience Vol. 53(11) November 2018 